\title{
Intergeneric distances between Ostrea, Crassostrea, and Saccostrea, studied by means of crossed immuno-electrophoresis
}

\author{
Vibeke Brock \\ Biology Institute, University of Odense, Campusvej 55, DK-5230 Odense M, Denmark
}

\begin{abstract}
Polyspecific antisera were obtained from rabbits for each of the following oyster species: Ostrea edulis (Linné) and O. Iurida (Carpenter), Crassostrea gigas (Thurnberg) and C. virginica (Gmelin), and Saccostrea commercialis (Iredale \& Roughley) and S. echinata (Quoy \& Gaimard). By means of crossed immuno-electrophoresis (CIE), genus-specific and genus-non-specific antigen-antibody reactions were recorded, in all 28 for Ostrea, 28 for Crassostrea, and 27 for Saccostrea. Genetic distances, defined by 1 - (number of genus-specific antigen-antibody reactions) $\div$ (number of genusspecific and genus-non-specific reactions), were 0.25 to 0.29 between Ostrea and Crassostrea, 0.32 to 0.33 between Ostrea and Saccostrea, and 0.22 to 0.26 between Crassostrea and Saccostrea. The results accord with the current distinction between Ostrea and the 2 other taxa and support the latters' division into the 2 genera Crassostrea and Saccostrea.
\end{abstract}

\section{INTRODUCTION}

In 1939 Iredale wrote the following, which describes a continuing problem:
'Though beloved by gourmets from earliest times, oysters have never been a delight to systematic conchologists.

Much controversy exists concerning the definition of genera within the pelecypod family, Ostreidae (Rafinesque, 1815). Dall (1898) separated Ostreidae into 2 groups, the monoecious (hermaphrodite) Ostrea (Linné, 1758), and the dioecious (separate sexes) Crassostrea (Sacco, 1897), and later Orton (1928) used the same criterion for defining his 2 genera Monoeciostrea' and 'Dioeciostrea'.

Lamy (1929) recognized only one genus, Ostrea, which he subdivided into 12 subgenera. Vialov (1936) recognized 116 fossil and live genera and subgenera. Iredale (1939) recognised 4 genera in his work on Australian oysters: Ostrea, Lopha (Roding, 1798), Saxostrea (Iredale, 1936), and Dendostrea (Swainson, 1835); his Saxostrea did not, however, include all the species comprising Saccostrea (see below). While Stenzel (1947) recognized 12 genera, Ranson (1948) arranged the Ostreidae species into 3 genera, Pycnodonte (Fisher de Waldheim, 1807), Gryphae (Lamarck, 1801), and Ostrea. Three years later, Gunter (1951) recognized 3 recent genera, Ostrea, Crassostrea (= Ranson's Gryphae), and Pycnodonte, a user-friendly taxonomy employed by e.g. Thomson (1954), Younge (1960), Galtsoff (1964) and Ahmed (1971). Carreon (1969) also recognized these 3 genera. He distinguished Ostrea from the other 2 by its relatively large gill ostia, its larviparity, and by absence of the promyal chamber (a passage situated on the right side of the visceral mass, between the adductor muscle and the hinge). Further, Pycnodonte was distinguished from Crassostrea by having a rectum which penetrates through the heart ventricle.

Stenzel's nomenclature (1947) was revised in 1971. He subdivided Ostreidae [which had been split apart from Gryphaeidae (Vialov 1936) including the subfamily Pycnodonteinae (Stenzel 1959)] into the 2 subfamilies, Ostreinae (Rafinesque 1815) and Lophinae (Vialow 1936). He recognized the following 4 genera of recent species as belonging to Ostreinae: Crassostrea, Saccostrea (Dollfus \& Dautzenberg 1920), Striostrea (Vialow 1936) and Ostrea. The arguments for splitting Dall's Crassostrea into 2 genera were that 'Saccostrea differs from Crassostrea in its deeper umbonal cavity, strong chromata, and tendency to conical rudistiform or cornucopia-like shapes' and 'eggs of S. cucullata have no effect in stimulating ejaculation of sperm from ripe 
males of $C$. virginica and species of these 2 genera cannot be made to crossfertilize each other' (Galtsoff \& Smith 1932, Menzel 1968).

Although Ostrea and Crassostrea have been used, Saccostrea seems now to be generally accepted as the genus name for the farmed Sydney rock oyster Saccostrea commercialis (Iredale \& Roughley) (e.g. Wisely et al. 1979, Braley 1984, Nell \& Dunkley 1984) and the New Zealand rock oyster S. glomerata (Gould) (Dinamani \& Lenz 1977), however see Dayton et al. (1989). Ahmed (1975) also recognized the genus Saccostrea, stressing that all tuberculated species of Crassostrea should in the future be assigned to Saccostrea, thus also the species $S$. echinata (Quoy \& Gaimard).

In the present investigation, genetic distances between the genera Ostrea, Crassostrea, and Saccostrea were studied by crossed immuno-electrophoresis using polyspecific rabbit-antibodies against O. edulis, O. luridae, C. gigas, C. virginica, S. echinata, and S. commercialis.

\section{MATERIALS AND METHODS}

Collection and storage of oyster material. Samples of 40 to 70 individuals were transported live to the laboratory. The following species were studied: Ostrea edulis (L.) from Northern Europe, (Limfjord, Denmark); O. Iurida (Carpenter) and Crassostrea gigas (Thurnberg) from the East Pacific (Oregon, USA); C. virginica (Gmelin) from the West Atlantic (New York, USA); Saccostrea commercialis (Iredale \& Roughley) from the West Pacific (New South Wales, Australia); and $S$. echinata (Quoy \& Gaimard), from the West Pacific (Queensland, Australia). Individual samples of hepatopancreas were pooled for each species, frozen at $-80^{\circ} \mathrm{C}$, and stored at $-40^{\circ} \mathrm{C}$. Shells of type specimens are kept at the Division of Invertebrate Zoology, Australian Museum, Sydney (S. commercialis: C. 163743 and S. echinata: C. 163744), and by the author.

Antigen preparation. Antigen samples were obtained from pooled hepatopancreas tissue homogenates from about 50 individuals of each of the species after starvation for 3 to $6 \mathrm{~d}$. Tissue samples were homogenized with physiological saline solution and diluted to obtain a protein concentration of about $15 \mathrm{mg}$, which was determined according to Lowry et al. (1951). All procedures were carried out at $0^{\circ} \mathrm{C}$.

Antibody formation. Formation of polyspecific rabbit antibodies was carried out for each of the 6 species. For each species, 2 rabbits were immunized by intramuscular injections with the antigen solution: the first and second times using $1 \mathrm{mg}$ antigen in Freund's complete adjuvant $(700 \mu \mathrm{l})$ and phosphate buffer $(750 \mu \mathrm{l})$ at $2 \mathrm{wk}$ intervals; thereafter, 4 injections at $1 \mathrm{wk}$ intervals with the same amount of antigen and buffer using Freund's incomplete adjuvant. One month after the last intramuscular injection, the rabbits immunized with Ostrea and Crassostrea antigens received an intravenal booster injection of $0.2 \mathrm{mg}$ antigen in physiological saline solution prior to total bleeding 2 wk later; the rabbits immunized with the Saccostrea antigens were bled 2 wk after the last muscular immunization. The booster injections had no evident effect upon the antibody concentrations. After removal of blood cells by centrifugation, $\mathrm{NaN}(0.1 \%)$ was added to the sera. Immunoglobulins were precipited with $\left(\mathrm{NH}_{4}\right)_{2} \mathrm{SO}_{4}(25 \mathrm{~g}$ per $100 \mathrm{ml}$ antiserum), dialyzed with frequent shifts of acetate buffer $(\mathrm{pH}=5)$ to precipitate lipoproteins, and diluted to original concentrations. Presence of immunoglobulins in the purified solution was stated by cellulose acetate electrophoresis, and immunoglobulin concentrations were determined by densiometric scanning. All preparations were carried out at $0^{\circ} \mathrm{C}$.

Titer determination and crossed immuno-electrophoresis (CIE). Antibody titres were assayed by immuno-electrophoresis using $5 \mu \mathrm{l}$ of each antigen solution and different amounts of the corresponding rabbit antibodies in an electrophoresis gel. The antibody solutions from each pair of rabbits immunized with the same antigens contained similar antibody titres and were mixed. These species-related antibody solutions were thereafter used in the study.

CIE was carried out as described earlier (Brock 1987). Antigen-antibody precipitates were identified on the gels which were stained lightly to identify pronounced precipitates, and then heavily to visualize weaker precipitates. Genus-specific reactions were substantiated by CIE by precipitation of genus-nonspecific reactions in an intermediary gel containing antibodies against one of the other genera and precipitation of genusspecific reactions in a receiver gel containing antibodies against the tested antigens (Brock 1987).

Determination of genetic distances. Genetic relations at intergeneric levels are expressed by numbers of shared (genus-non-specific) antigen-antibody reactions, related to numbers of possible (genus-nonspecific + genus-specific) antigen-antibody reactions. Distances are calculated by a dissimilarity coefficient, 1 - X (Dino \& Georgi 1982), where $\mathrm{X}=$ a non-weighted, simple matching coefficient obtained by dividing the number of shared antigen-antibody reactions by the total number of identified antigen-antibody reactions.

\section{RESULTS}

Numbers of recorded antigen-antibody reactions for each of the 3 oyster genera are listed in Table 1 . Antigen-antibody reactions obtained with one or both of the 2 species of a genus are considered 'genus- 
Table 1. Ostrea, Crassostrea, and Saccostrea. Genus-specific plus genus-non-specific (bold), and genus-non-specific antigen-antibody reactions (normal print) recorded by crossed immuno-electrophoresis. For example, antigens from Crassostrea give 20 detected reactions with antibodies against Saccostrea, while antigens from Saccostrea give 21 detected reactions with antibodies against Crassostrea. Oe: Ostrea edulis; Ol: O. lurida; $\mathrm{Cg}$ : Crassostrea gigas; $\mathrm{Cv}$ : C. virginica; Sc: Saccostrea commercialis; Se: S. echinata

\begin{tabular}{|llll|}
\hline & \multicolumn{3}{c|}{ Antibodies against: } \\
& $\mathrm{Oe}+\mathrm{Ol}$ & $\mathrm{Cg}+\mathrm{Cv}$ & $\mathrm{Sc}+\mathrm{Se}$ \\
Antigens from: & & & \\
\hline $\mathrm{Oe}+\mathrm{Ol}$ & $\mathbf{2 8}$ & 21 & 19 \\
$\mathrm{Cg}+\mathrm{Cv}$ & 20 & $\mathbf{2 8}$ & 20 \\
$\mathrm{Sc}+\mathrm{Se}$ & 18 & 21 & $\mathbf{2 7}$ \\
\hline
\end{tabular}

characteristic' (not genus-specific) antigens. By counting the antigen-antibody reactions which are genusspecific, and those which are genus-characteristic but genus-non-specific, calculation of genetic distances between the genera is possible. The calculated genetic distance was found to be 0.29 between the genera Ostrea and Crassostrea, when Crassostrea antigens reacted with antibodies against Crassostrea (28 precipitates) and with antibodies against Ostrea (20 precipitates). When Ostrea antigens reacted with antibodies against Ostrea ( 28 precipitates) and antibodies against Crassostrea (21 precipitates), the same genetic distance was found to be 0.25 . The genetic distance between Ostrea and Saccostrea was found to be 0.33 when Saccostrea antigens reacted with antibodies against Saccostrea (27 precipitates) and antibodies against Ostrea (18 precipitates) and 0.32 when Ostrea antigens reacted with antibodies against Ostrea $(28$ precipitates) and antibodies against Saccostrea (19 precipitates). The genetic distance between Crassostrea and Saccostrea was found to be 0.26 when Crassostrea antigens reacted with antibodies against Crassostrea (28 precipitates) and antibodies against Saccostrea (20 precipitates), and 0.22 when Saccostrea antigens reacted with antibodies against Saccostrea (27 pre- cipitates) and antibodies against Crassostrea (21 precipitates). Table 2 shows the calculated genetic distances.

\section{DISCUSSION}

The genus Crassostrea was separated from Ostrea by biological ('natural') criteria such as egg size (Walne 1964), whether a species is dioecious or monoecious Orton (1928), and on cytological chromosome differences (Ahmed 1973). Most bivalves are dioecious, e.g. Crassostrea and Saccostrea, therefore the monoecious Ostrea was considered more specialized (Stenzel 1971). The idea that Ostrea is a recently evolved form has also been proposed by Ahmed (1975) who suggested that Ostrea evolved from a Crassostrea-like ancestor through tight chromosome coiling. His work shows that species from 3 different genera, O. lurida, C. gigas, and $S$. commercialis, each contain the same chromosome number $(2 \mathrm{~N}=20)$; this constant number neither supports nor contradicts the assumption that Ostrea is a more recently evolved genus than Crassostrea. However, Ahmed's theory is consistent with the fossil records (Stenzel 1971) which show that Crassostrea is older than Ostrea (earlier Cretaceous versus Cretaceous). The recent fossils of Saccostrea (Miocene) together with the present results suggest that this genus may have evolved from a Crassostrea and not from an Ostrea form. (The evolution of Ostreiidae is currently under study using comparisons of repetitive DNA sequences; Brock \& Christiansen 1989).

In an immuno-absorbance assay, Numacki (1962) demonstrated the existence of 5 non-quantified genusspecific antigen-antibody reactions for the Crassostrea species C. gigas, C. angulata, C. rivularis and C. virginica as compared to $O$. edulis, whereas the Crassostrea types could not be separated from each other by the method used. In a comparison of the 2 intensely studied Mytilus forms, M. edulis and M. galloprovincialis, Brock (1985) could not separate them by means of CIE as the 2 forms shared all 27 identified antigenantibody reactions, while the difference between the

Table 2. Ostrea, Crassostrea, and Saccostrea. Genetic distances between the 3 genera calculated from the results presented in Table 1 using the expression:

$$
\text { Genetic distance }=1-\frac{\text { antigen-antibody reactions shared by the } 2 \text { genera }}{\text { total no. of antigen-antibody reactions for the } 2 \text { genera }}
$$

\begin{tabular}{|c|c|c|c|}
\hline Genetic distance between: & Ostrea & $\begin{array}{c}\text { Antigens from: } \\
\text { Crassostrea }\end{array}$ & Saccostrea \\
\hline Ostrea and Crassostrea & 0.25 & 0.29 & \\
\hline Ostrea and Saccostrea & 0.32 & & 0.33 \\
\hline Crassostrea and Saccostrea & & 0.26 & 0.22 \\
\hline
\end{tabular}


Table 3. Methods suitable for measuring different forms of genetic variability and distances. Unless modified, methods for measuring smaller genetic distances are unproportionally resource-consuming when applied to larger genetic distances

\begin{tabular}{|c|c|c|c|c|c|}
\hline Method & $\begin{array}{c}\text { Intra- } \\
\text { individual }\end{array}$ & $\begin{array}{c}\text { Inter- } \\
\text { individual }\end{array}$ & $\begin{array}{c}\text { Inter- } \\
\text { population }\end{array}$ & $\begin{array}{l}\text { Inter- } \\
\text { specific }\end{array}$ & $\begin{array}{l}\text { Inter- } \\
\text { generic }\end{array}$ \\
\hline cDNA sequence analysis & $x$ & $x$ & $x$ & $x$ & $x$ \\
\hline Fingerprinting with probes & $x$ & $x$ & $x$ & $x$ & $x$ \\
\hline Protein/isozyme analyses & $x$ & $x$ & $x$ & $x$ & $x$ \\
\hline Immunology & & $x$ & $x$ & $x$ & $x$ \\
\hline Physiology & & $\times$ & $x$ & $\times$ & $x$ \\
\hline Morphology & & $x$ & $x$ & $x$ & $x$ \\
\hline Gamete hybridization & & & & $\times$ & $x$ \\
\hline
\end{tabular}

genera Mytilus and Musculus was found to be 0.30 . In a similar study, the genetic distance between the genera Acanthocardia and Cerastoderma amounted to 0.63 (Brock 1989). This pronounced distance supports taxonomists in finding the 2 genera sufficiently different to be referred to distinct subfamilies. The genetic distance between the 2 genera Musculus and Mytilus is in good agreement with the distances between the 3 studied Ostreidae taxa found in this study and supports their separation into different genera. The classification by Harry (1985), according to which Ostrea is referred to the subfamily Ostreinae while Crassostrea and Saccostrea are referred to Crassostreinae is not confirmed, however it is not challenged by the present results since the distances between Ostrea and the 2 other genera are somewhat larger than the distance between them.

The visualized antigen-antibody reactions represent only soluble proteins which are large enough to act as antigens, and which occur in concentrations high enough to give rise to substantial antibody formation in rabbits. Thus only those proteins present in most of the oyster individuals, and not rare ones, will be detected. Also, the subtler differences between taxa are not registered by the method because the antigen-antibody reactions obtained are not unambiguously defined since different proteins may hold similar epitopes (antigen determinants) and therefore react with the same antibody. All this means that the immunological method used would probably be too coarse for measuring genetic distances at a subspecies level. For that purpose classical population comparisons based on isozyme studies (e.g. Buroker et al. 1979, Buroker 1983) and studies of DNA-variation are finer and hence more suitable tools (Brock 1989). However, as shown in Table 3, other immunological methods may be used for studies of inter-individual and inter-population distances, and intrageneric immunological differences and similarities are currently being studied with the inclusion of more species. For the present study, the method was purposely chosen for measure- ments of supraspecific distances since by ignoring the subtler inter-individual and inter-population details, the larger scale differences emerge.

In conclusion, independent immunological study of genetic distances between the oyster taxa Ostrea, Crassostrea, and Saccostrea strongly supports Orton's and Walne's separation of the genus Ostrea from Dall's Crassostrea. Further, it substantiates Stenzel's division of Dall's Crassostrea into the 2 distinct genera Crassostrea and Saccostrea.

Acknowledgements. I am thankful to all colleagues in Europe, North America, and Australia who helped me to obtain the oyster samples, to colleagues at The University of Aarhus, The Royal Danish School of Veterinary Medicine, and The National Institute of Animal Science, Denmark, for helping me with immunization of the 20 rabbits, and with antigen and antisera preparations. I also thank Lizard Island Research Station and The Australian Institute of Marine Science, Australia, where part of the study was carried out, and where I received superb help and support, and The Great Barrier Marine Park Authorities for allowing me to collect oysters from the Great Barrier Reef. Finally I want to express my sincere gratitude to The Carlsberg Foundation who supported this study entirely.

\section{LITERATURE CITED}

Ahmed, M. (1971). Oyster species of West Pakistan. Pakistan J. Zool. 3 (2): 229-236

Ahmed, M. (1973). Cytogenetics of oysters. Cytologia 38: 337-346

Ahmed, M. (1975). Speciation in living oysters. Adv. mar. Biol. 13: $357-397$

Braley, R. D. (1984). Mariculture potential of introduced oysters Saccostrea cucullata tuberculata and Crassostrea echinata, and a histological study of reproduction of $C$. echinata. Aust. J. mar. Freshwat. Res. 35: 129-141

Brock, V. (1985). Immuno-electrophoretic studies of genetic relations between populations of Mytilus edulis and Mytilus galloprovincialis from the Mediterranean, Baltic, East and West Atlantic, and East Pacific. In: Gibbs, P. E. (ed.) Proc. 19th Eur. Mar. Biol. Symp. Cambridge University Press, Cambridge, p. $515-520$

Brock, V. (1987). Genetic relations between the bivalves Cardium (Cerastoderma) edule, Cardium lamarcki, and Car- 
dium glaucum, studied by means of crossed immunoelectrophoresis. Mar. Biol. 93: 483-488

Brock, V. (1989). Supra-, inter- and intra-specific distances in a complex of Cardiidae (Mollusca, Bivalvia): studies of immunological heterogeneity, biometry, and DNA variation. In: Miyachi, S., Karube, I., Ishida, Y. (eds.) Current topics in marine biotechnology. Proc. of the 1st International Marine Biotechnology Conference. Fuji Technology Press, Ltd, Tokyo, p. 315-318

Brock, V., Christiansen, G. (1989). Evolution of Cardium (Cerastoderma) edule, C. lamarcki, and C. glaucum; studies of DNA variation. Mar. Biol. 102: 505-511

Buroker, N. E. (1983). Population genetics of the American oyster Crassostrea virginica along the Atlantic coast and the Gulf of Mexico. Mar. Biol. 75: 99-112

Buroker, N. E., Hershberger, W. K., Chew, K. K. (1979). Population genetics of the family Ostreidae. II. Interspecific studies of the genera Crassostrea and Saccostrea. Mar. Biol. 54: 171-184

Carreon, J. A. (1969). The malacology of Philippine oysters of the genus Crassostrea and a review of their shell characters. Proc. natn. Shellfish. Ass. 59: 104-114

Dall, W. H. (1898). Tertiary fauna of Florida. Superfamily Ostracea. Trans. Wagner Free Inst. Sci. Philadelphia 3 (4): 671-688

Dayton, P. K., Carleton, J. H., Mackley, A. G., Sammarco, P. W. (1989). Patterns of settlement, survival and growth of oysters across the Great Barrier Reef. Mar. Ecol. Prog. Ser. 54: $61-73$

Dinamani, P., Lenz, P. A. (1977). Some aspects of spatfall of the New Zealand rock oyster during 1974. Veliger 20 (1): $17-26$

Dino, F., Giorgi, F. (1982). Electrophoretic analysis of Euplotes crassus stocks from populations differing in their breeding systems. Can. J. Zool. 60: 929-932

Galtsoff, P. S. (1964). The American oyster Crassostrea virginica Gmelin. U.S. Fish Wildl. Serv. Fish. Bull. 64: $1-480$

Galtsoff, P. S., Smith, R. O. (1932). Stimulation of spawning and crossfertilization between American and Japanese oysters. Science 76: 371-372

Gunter, G. (1951). The species of oysters of the Gulf, Carib-

This article was presented by Dr P. W. Sammarco, Canberra, Australia bean and West Indian Region: the genera of Ostreidae. Bull. mar. Sci. Gulf Caribb. 1 (1): 40-45

Harry, H. V. (1985). Synopsis of the supraspecific classification of living oysters (Bivalvia: Gryphaeidae and Ostreidae). Veliger 28 (2): 121-158

Iredale, T. (1939). Mollusca. Great Barrier Reef Expedition 1928-29. Scientific Reports 5 (6): Mollusca, Part I. British Museum (Nat. Hist.), London, p. 209-425

Lamy, E. (1929). Revision de Ostrea vivantes du Museum National d'Histoire Naturelle de Paris. J. Conchyliol. 73: $1-46,71-168,233-275$

Lowry, O. H., Rosebrough, N. J., Farr, A. L., Randall, R. J. (1951). Protein measurement with the Folin phenol reagent. J. biol. Chem. 193: 265-275

Menzel, R. W. (1968). Cytotaxonomy of species of clams (Mercenaria) and oysters (Crassostrea). Proc. Symp. Mollusca Ernaculum Cochin. Mar. Biol. Ass. India, I, p. 53-58

Nell, J. A., Dunkley, P. R. (1984). L-methionine uptake by Saccostrea commercialis. Mar. Biol. 80: 335-339

Numacki, K.-I. (1962). Serological studies of species and races in oysters. Am. Nat. 96: 211-217

Orton, J. H. (1928). The dominant species of Ostrea. Nature, Lond. 121: 320-321

Ranson, G. (1948). Prodissoconques et classification des Ostreides vivants. Bull. Mus. Hist. nat. Belg. 24 (42): 1-12

Stenzel, H. B. (1947). Nomenclatural synopsis of supraspecific groups of the famely Ostreidae (Pelecypoda, Mollusca). J. Paleont. 21 (2): 165-185

Stenzel, H. B. (1971). In: Moore, K. C. (ed.) Treatise on invertebrate paleontology, Part N, Mollusca, 6, 3. Geol. Soc. Am., Kansas, p. 953-1224

Thomson, J. M. (1954). The genera of oysters and the Australian species. Aust. J. mar. Freshwat. Res. 5: 132-168

Vialov, O. (1936). Sur la classification de huitres. C. R. (Dokl.) Acad. Sci. URSS New Ser. Vol. 4, 13, no. 1: 17-20

Walne, P. R. (1964). Observations of the fertility of the oyster (Ostrea edulis). J. mar, biol. Ass. U.K. 44: 293-310

Wisely, B., Holliday, J. E., Reid, B. L. (1979). Experimental deepwater culture of the Sydney rock oyster (Crassostrea commercialis $=$ Saccostrea cucullata) $\mathrm{I}$. Growth of vertical clumps of oysters ('ren'). Aquaculture 16: 127-140

Yonge, C. M. (1960). Oysters. Collins, London

Manuscript first received: November 12, 1989

Revised version accepted: August 17, 1990 